\title{
Ecological Implications of Acorn Size at the Individual Tree Level in Quercus suber $\mathrm{L}$.
}

\author{
Soledad Ramos, ${ }^{1}$ Francisco M. Vázquez, ${ }^{2}$ and Trinidad Ruiz ${ }^{3}$ \\ ${ }^{1}$ Departamento de Ingeniería del Medio Agronómico y Forestal, Escuela de Ingenierías Agrarias, \\ Universidad de Extremadura, Avendia Adolfo Suárez s/n, 06007 Badajoz, Spain \\ ${ }^{2}$ Departamento de Producción Forestal, Centro de Investigación La Orden-Valdesequera, Consejería de Infraestructura y Desarrollo \\ Tecnológico, Junta de Extremadura, Apartado de Correos 22, 06080 Badajoz, Spain \\ ${ }^{3}$ Departamento de Biología Vegetal, Ecología y Ciencias de la Tierra, Área de Botánica, Facultad de Ciencias, \\ Universidad de Extremadura, Avendia de Elvas s/n, 06006 Badajoz, Spain
}

Correspondence should be addressed to Soledad Ramos; solesuber@yahoo.es

Received 10 June 2013; Accepted 10 July 2013

Academic Editors: S. Ogita, S.-W. Park, and T. Vogt

Copyright (C) 2013 Soledad Ramos et al. This is an open access article distributed under the Creative Commons Attribution License, which permits unrestricted use, distribution, and reproduction in any medium, provided the original work is properly cited.

\begin{abstract}
Few studies have determined the influence of acorn size on germination and predation percentage at tree level. To evaluate the seed size influence at individual tree level, trees producing two different sizes of acorn were chosen. Our results show that smaller acorns were significantly more infested (49.6-75.3\%) than larger ones (11.0-27.33\%). About germination, big acorns achieved the best germination percentage compared to the smaller ones (18\% in infested and $76 \%$ in sound acorns for the small acorn group versus $69.3 \%$ in infested and $93.3 \%$ in sound acorns belonging to the big acorn group). We also found that there was a difference in behaviour between big and small seeds at tree level. The same size belonging to different functional groups presented a difference at the behavioural level per tree. Infested small acorns from trees 8 and 10 had only 33 and 13\% germination, while big acorns from trees 2,3 , and 6 (there was no difference between both sizes) presented 67,97 , and $83 \%$, respectively. These results indicate that the production of acorns with two different sizes could be a strategy for species regeneration, producing each size for a different purpose.
\end{abstract}

\section{Introduction}

Quercus L. is a genus that produces a great acorn-size variation within the species and even at the individual tree level. Some Mediterranean Quercus species, such as holm oak $(Q$. ilex L.) and cork oak (Q. suber L.), frequently bloom twice a year. Male flowering, female flowering, or both may happen in spring and again in autumn [1-3]. Most of these species need only one season to complete the cycle (from flower until seed maturity) whereas others require two years. Both annual and biennial acorns are found in various species of the subgenus Cerris. Cork oak, however, is the only known oak species with annual and biennial acorns on the same tree [4-6]. Many female flowers show an annual cycle, with anthesis in spring or autumn and mature fruits during the same year. Several trees also produce biennial acorns with anthesis in spring or autumn of the first year and fruit set in the second year. All of this could be the origin of acorn size variability because spring flowering has more time to grow than autumn ones in annual cycle. Furthermore, the biennial flowering has more time than annual ones. All of these reasons make cork oak a very interesting species that produces acorn from September to January with different sizes and different origins.

Researchers have been interested in that variability, producing many works about the relationship between acorn size and germination or seedling production in cork oak [7-9] and in other species [10-14]. However, all of those studies of this trait have been carried out at the stand level not at the individual tree level. Only Tecklin and McCreary [15], working with blue oak at this level, found that the different behaviours from diverse acorn sizes were due not only to the size but also for each mother tree. This variability could be a reproductive strategy, because it is well known that one size of fruit is not favourable from an evolutionary point of view. Predators usually are adapted to attack a narrow range of fruit size $[16,17]$. 
In accordance with previously published work, which aimed to determine the reproductive behaviour of cork oak [18], we proposed to understand the reason that this species produces different acorn sizes at the individual tree level. Specifically, the goals of this work were (a) to study biometrically the acorns to justify the existence of both big and small acorns; (b) to analyze the relationship between acorn size and germination; and (c) to analyze the relationship between acorn size and infestation percentage.

\section{Materials and Methods}

2.1. Plant Material. The study was conducted in a mountainous area in South-Western Spain-Sierra de Jerez de los Caballeros located at $500-693 \mathrm{~m}$ above sea level (UTM 29SQC94)-that is covered by holm oak and cork oak forming dehesa systems.

Acorns were collected from the ground beneath trees during November (at this time most of the acorns are on the ground [19]). To evaluate the influence of acorn size at the individual tree level, we selected seventeen cork oak that fulfilled the following conditions: they had two clearly different acorn sizes (big and small), without intermediate sizes, and their crowns did not overlapp any tree to avoid picking up acorns belonging to another individual. To carry out the different studies, 200 acorns per individual were randomly collected, 100 per each class of acorn size. Samples were identified by a number and letter according to their mother tree and class size and placed in plastic bags to be transported and stored at $4^{\circ} \mathrm{C}$ in the refrigerator.

2.2. Acorn Biometry Determination and Infestation Study. In order to ratify the variability of acorn size at the individual tree from the 200 stored acorns in the refrigerator, 50 acorns were randomly chosen, 25 from each class of acorn size (850 acorns in total). In these samples, after removing the cupules, length and width were measured to calculate the acorn volume according to the formulae designed for this kind of acorns by Ramos [18]. The acorns without holes could present larvae inside for that those acorns, after being measured, were carefully dissected and examined for the presence of predators (insects) or their remains.

2.3. Acorn Germination. The germination test was carried out two days after to be collected, in order to avoid loss of viability. Germination was studied in 3 replicas of 10 acorns each one from each collected sample, 30 were infested (acorns with insect holes) and the other 30 were apparently sound (without insect holes) with a total of 60 acorns studied per individual. In order to verify the absence of larvae, cotyledons were removed after seedling emergence. Whole sets were stratified on wet sand and were placed in a room simulating the environmental conditions of the natural population when the acorn germination is carried out (oscillation day/night aprox. $3^{\circ} \mathrm{C}$ to $18^{\circ} \mathrm{C}$ ). Germination was recorded every 2-3 days for three months, and the acorns were watered when necessary. They were considered germinated when the radicle protruded about $2 \mathrm{~mm}$.
TABLE 1: Nested ANOVA of the variation of the acorn volume according to acorn class (small versus big) nested within individual tree in Quercus suber.

\begin{tabular}{lcccc}
\hline & DF & MS & $F$ & $P$ \\
\hline Tree & 16 & 48.930 & 60.437 & 0.000 \\
Acorn class (tree) & 17 & 137.694 & 170.077 & 0.000 \\
Error & 811 & 0.810 & & \\
\hline
\end{tabular}

DF: degree of freedom; MS: mean square based on type III sums of squares.

2.4. Statistical Analysis. The statistical analyses were chosen according to Sokal and Rohlf [20] and were carried out with Statistical Software SPSS 15.0 for Windows [21]. After testing normality of the acorn volume variable using the Kolmogorov-Smirnov test with Lilliefors correction and Homoskedasticity using Levene's test, comparison of means was analyzed by a nested ANOVA with individual as principal factor and acorn class nested within the individual. Post hoc comparisons were analyzed using Tukey's HSD. The relationship between small and big acorn classes within individuals was analyzed using Pearson linear correlation. The comparison of acorn infestation and germination percentage was analyzed using the Pearson chi-square test by means of a two-factor (Row x Column) contingency table.

\section{Results}

3.1. Acorn Biometry. Acorn biometry was significantly different among individuals and class acorn nested within individuals (Table 1). The volume average varied between 1.65 and $3.91 \mathrm{cc}$ in the small group and from 3.49 to $8.56 \mathrm{cc}$ in the big group (Table 2). The individuals 8 and 10 could be stadistically separated of the other trees. However, the small acorn class of the 8 and 10 individuals was overlapping with the big acorn class belonging to other individuals, mainly to 1 , $2,3,6$, and 16 individuals. In spite of that, those small acorns had a different behaviour compared with those small acorns as we will comment hereinafter (Table 3).

By other hand, a significant positive correlation was found between the two acorn sizes at the individual tree level $(r=$ $0.845, P<0.001)$, that is, the higher acorn size of the big class, the higher acorn size of the small class. For this reason, it could be possible to consider trees 8 and 10 different from the rest (Figure 1).

3.2. Acorn Infestation and Germination. At population level, significant differences among acorn size were observed in the percentage of infested acorns $\left(\chi^{2}=154.87, P<0.001\right.$, Table 2). The mean percentage in the small class varied between 16 and $100 \%$, while this variable in the big class ranged from 0 to $68 \%$. At the individual tree level, there were significant differences in infestation between small and big acorns, being always lower infestation in big acorns, even some trees (8 and 9 ) presented $0 \%$ in this class (Table 2 ).

Infestation caused a significant reduction in germination percentage in both acorn classes, but this phenomenon was most intense and common in small acorns (Table 2, i.e, tree 2 small sound $43.33 \%$ versus small infested $0 \%$ and big 
TABLE 2: Mean values of volume (cc), infestation, and germination percentage (sound versus infested) of both small and big acorn classes at individual tree level. In parentheses is shown the value of chi-square test and significance when comparing small versus big acorns.

\begin{tabular}{|c|c|c|c|c|c|c|}
\hline \multirow{2}{*}{ Tree } & \multirow{2}{*}{ Class } & \multirow{2}{*}{ Volume $^{\mathrm{a}}$} & \multirow{2}{*}{ Infestation $\left(\chi^{2}\right)$} & \multicolumn{2}{|c|}{ Germination } & \multirow{2}{*}{$\chi^{2^{b}}$} \\
\hline & & & & Sound $\left(\chi^{2}\right)$ & Infested $\left(\chi^{2}\right)$ & \\
\hline \multirow{2}{*}{1} & Small & $2.06 \pm 0.43^{* * *}$ & $16\left(0.76^{\text {ns }}\right)$ & $100\left(0.00^{\text {ns }}\right)$ & 63.33 & $13.47^{* *}$ \\
\hline & Big & $3.49 \pm 0.59$ & 8 & 100 & - & - \\
\hline \multirow{2}{*}{2} & Small & $1.78 \pm 0.54^{* * *}$ & $96\left(6.64^{* *}\right)$ & $43.33\left(8.53^{* *}\right)$ & $0\left(30.00^{* * *}\right)$ & $16.60^{* * *}$ \\
\hline & Big & $4.36 \pm 0.92$ & 68 & 80 & 66.67 & $1.36^{\mathrm{ns}}$ \\
\hline \multirow{2}{*}{3} & Small & $1.65 \pm 0.37^{* * *}$ & $68\left(13.88^{* * *}\right)$ & $96.67\left(0.00^{\mathrm{ns}}\right)$ & $10\left(45.27^{* * *}\right)$ & $45.27^{* * *}$ \\
\hline & Big & $4.66 \pm 0.95$ & 16 & 96.67 & 96.67 & $0.00^{\mathrm{ns}}$ \\
\hline \multirow{2}{*}{4} & Small & $1.99 \pm 0.61^{* * *}$ & $100\left(25.76^{* * *}\right)$ & $56.67\left(10.76^{* *}\right)$ & $13.33\left(32.27^{* * *}\right)$ & $12.38^{* * *}$ \\
\hline & Big & $5.55 \pm 1.24$ & 32 & 93.33 & 86.96 & $0.74^{\mathrm{ns}}$ \\
\hline \multirow{2}{*}{5} & Small & $2.32 \pm 0.68^{* * *}$ & $80\left(8.33^{* *}\right)$ & $66.67\left(12.00^{* *}\right)$ & $16.67\left(39.10^{* * *}\right)$ & $15.43^{* * *}$ \\
\hline & Big & $6.71 \pm 1.55$ & 40 & 100 & 96.67 & $1.02^{\mathrm{ns}}$ \\
\hline \multirow{2}{*}{6} & Small & $2.16 \pm 0.49^{* * *}$ & $44\left(8.42^{* *}\right)$ & $90\left(0.22^{\mathrm{ns}}\right)$ & $36.67\left(13.61^{* * *}\right)$ & $18.37^{* * *}$ \\
\hline & Big & $4.48 \pm 0.95$ & 8 & 93.33 & 83.33 & $1.46^{\mathrm{ns}}$ \\
\hline \multirow{2}{*}{7} & Small & $1.87 \pm 0.52^{* * *}$ & $44\left(2.88^{\mathrm{ns}}\right)$ & $80\left(2.31^{\mathrm{ns}}\right)$ & $16.67\left(42.86^{* * *}\right)$ & $24.09^{* * *}$ \\
\hline & Big & $5.89 \pm 1.57$ & 20 & 93.33 & 100 & $2.07^{\mathrm{ns}}$ \\
\hline \multirow{2}{*}{8} & Small & $3.75 \pm 0.73^{* * *}$ & $44\left(14.10^{* * *}\right)$ & $93.33\left(4.09^{*}\right)$ & 33.33 & $23.25^{* * *}$ \\
\hline & Big & $8.56 \pm 0.86$ & 0 & 100 & - & \\
\hline \multirow{2}{*}{9} & Small & $2.86 \pm 0.75^{* * *}$ & $88\left(39.29^{* * *}\right)$ & $83.33\left(12.86^{* * *}\right)$ & 40 & $10.00^{* *}$ \\
\hline & Big & $6.59 \pm 0.60$ & 0 & 100 & - & \\
\hline \multirow{2}{*}{10} & Small & $3.91 \pm 0.67^{* * *}$ & $72\left(24.53^{* * *}\right)$ & $93.33\left(1.55^{\mathrm{ns}}\right)$ & 13.33 & $38.57^{* * *}$ \\
\hline & Big & $8.56 \pm 0.91$ & 4 & 98.33 & - & \\
\hline \multirow{2}{*}{11} & Small & $2.74 \pm 0.71^{* * *}$ & $84\left(5.88^{*}\right)$ & $71.43\left(5.46^{* *}\right)$ & $16.67\left(10.34^{* * *}\right)$ & $17.38^{* * *}$ \\
\hline & Big & $5.64 \pm 0.95$ & 52 & 93.33 & 56.67 & $10.76^{* *}$ \\
\hline \multirow{2}{*}{12} & Small & $2.61 \pm 0.65^{* * *}$ & $72\left(6.52^{*}\right)$ & $73.33\left(6.41^{* *}\right)$ & $20\left(7.18^{* *}\right)$ & $17.14^{* * *}$ \\
\hline & Big & $5.35 \pm 0.98$ & 36 & 96.67 & 53.33 & $15.02^{* * *}$ \\
\hline \multirow{2}{*}{13} & Small & $2.55 \pm 0.72^{* * *}$ & $52\left(4.16^{*}\right)$ & $93.33\left(0.35^{\mathrm{ns}}\right)$ & $0\left(10.59^{* * *}\right)$ & $52.50^{* * *}$ \\
\hline & Big & $5.53 \pm 1.68$ & 24 & 96.67 & 29.63 & $28.71^{* * *}$ \\
\hline \multirow{2}{*}{14} & Small & $1.87 \pm 0.88^{* * *}$ & $76\left(3.13^{\mathrm{ns}}\right)$ & $36.67\left(27.81^{* * *}\right)$ & $0\left(7.935^{* *}\right)$ & $13.47^{* * *}$ \\
\hline & Big & $4.90 \pm 1.03$ & 52 & 100 & 23.33 & $37.30^{* * *}$ \\
\hline \multirow{2}{*}{15} & Small & $2.16 \pm 0.57^{* * *}$ & $32\left(0.94^{\mathrm{ns}}\right)$ & $80\left(2.59^{\mathrm{ns}}\right)$ & 3.33 & $36.27^{* * *}$ \\
\hline & Big & $5.04 \pm 0.95$ & 20 & 63.33 & - & \\
\hline \multirow{2}{*}{16} & Small & $2.01 \pm 0.47^{* * *}$ & $76\left(2.73^{* * *}\right)$ & $63.33\left(5.43^{*}\right)$ & 3.33 & $24.30^{* * *}$ \\
\hline & Big & $4.18 \pm 1.35$ & 8 & 85 & - & \\
\hline \multirow{2}{*}{17} & Small & $1.78 \pm 0.77^{* * *}$ & $72\left(24.53^{* * *}\right)$ & $66.67\left(9.02^{* *}\right)$ & 13.33 & $17.78^{* * *}$ \\
\hline & Big & $5.27 \pm 1.09$ & 4 & 96.67 & - & $0.00^{\mathrm{ns}}$ \\
\hline
\end{tabular}

${ }^{a}$ Significant differences between big and small acorns within the tree after nested ANOVA with class acorn nested in individual.

${ }^{\mathrm{b}} \mathrm{Chi}$-square value and significance to compare germination between sound and infested acorns for each class per tree.

-indicate those trees that didn't present acorns apparently infested to be tested to germination.

ns: not significant; ${ }^{*} P<0.05 ;{ }^{* *} P<0.01 ;{ }^{* * *} P<0.001$.

sound $80 \%$ versus big infested $66.67 \%)$. When considering exclusively infested or sound acorns, the germination percentage was always higher or sometimes similar in big acorns, although this difference was stronger inside the infested acorns (Table 2, i.e, tree 2 small sound $43.33 \%$ versus big sound $80 \%$ and small infested $0 \%$ versus big infested $66.67 \%$ ).

The volume of the small class to trees 8 and 10 was overlapped with the big class of trees 1, 2, 3, 6, and 16. In spite of this the infestation percentage is significantly higher in the small acorn of those individuals than in the big acorns of the other trees (Table 3 ). In addition the reduction of germination percentage is higher in small acorns of individuals 8 and
10. In the case of sound acorns these differences disappear, only tree 1 showing $100 \%$ of germination differs significantly.

\section{Discussion}

4.1. Individual Tree Importance. One of the most relevant results obtained in this study is the role played by the individual tree. A significant difference was found between the two nearest sizes belonging to different volume class (i.e., 8 and $10 \mathrm{~S}$ versus $1,2,3,6$, and $16 \mathrm{~B}$ ) in germination and infestation levels. These results indicate that size is important even at the individual tree level. Had it not been differentiated by tree 
TABLE 3: Acorn infestation and germination percentage of small acorn class (S) belonging to individuals 8 and 10 (bold type) and big acorn class (B) belonging to individuals $1,2,3,6$, and 16 which size are statistically the same (mean \pm S.E.).

\begin{tabular}{|c|c|c|c|c|}
\hline \multirow{2}{*}{ Individual } & \multirow{2}{*}{ Class acorn } & \multirow{2}{*}{ Infestation } & \multicolumn{2}{|c|}{ Germination } \\
\hline & & & Sound & Infested \\
\hline 8 & $\mathbf{S}$ & 44 & 93.33 & 33.33 \\
\hline 1 & B & $12\left(8.42^{* *}\right)$ & $100\left(4.09^{*}\right)$ & - \\
\hline 2 & B & $68\left(2.92^{\mathrm{ns}}\right)$ & $80\left(2.31^{\mathrm{ns}}\right)$ & $66.67\left(6.67^{* *}\right)$ \\
\hline 3 & B & $16\left(4.67^{*}\right)$ & $96.67\left(0.35^{\mathrm{ns}}\right)$ & $96.67\left(26.45^{* * *}\right)$ \\
\hline 6 & B & $8\left(8.42^{* *}\right)$ & $93.33\left(0.00^{\mathrm{ns}}\right)$ & $83.33\left(15.43^{* * *}\right)$ \\
\hline 16 & $\mathrm{~B}$ & $8\left(8.42^{* *}\right)$ & $85\left(1.30^{\mathrm{ns}}\right)$ & - \\
\hline 10 & $S$ & 72 & 93.33 & 13.33 \\
\hline 1 & B & $12\left(21.33^{* * *}\right)$ & $100\left(4.09^{*}\right)$ & - \\
\hline 2 & B & $68\left(0.10^{\mathrm{ns}}\right)$ & $80\left(2.31^{\mathrm{ns}}\right)$ & $66.67\left(17.78^{* * *}\right)$ \\
\hline 3 & $\mathrm{~B}$ & $16\left(15.91^{* * *}\right)$ & $96.67\left(0.35^{\mathrm{ns}}\right)$ & $96.67\left(42.09^{* * *}\right)$ \\
\hline 6 & B & $8\left(21.33^{* * *}\right)$ & $93.33\left(0.00^{\mathrm{ns}}\right)$ & $83.33\left(29.43^{* * *}\right)$ \\
\hline 16 & $\mathrm{~B}$ & $8\left(21.33^{* * *}\right)$ & $85\left(1.30^{\mathrm{ns}}\right)$ & - \\
\hline
\end{tabular}

ns: no significant; ${ }^{*} P<0.05 ;{ }^{* *} P<0.01 ;{ }^{* * *} P<0.001$.

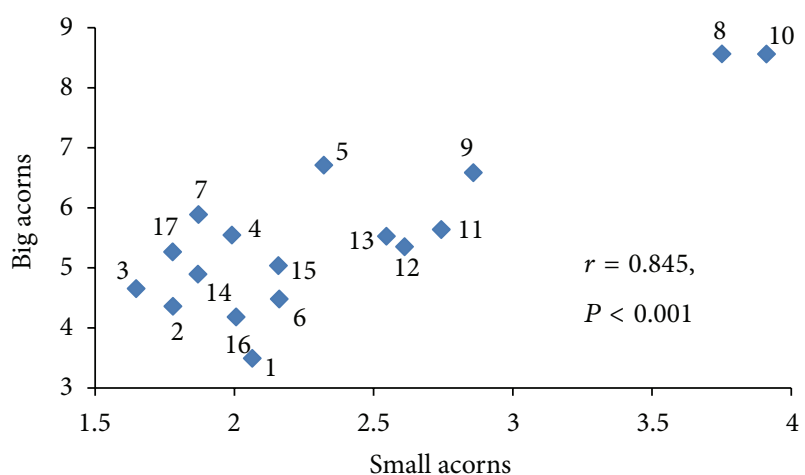

FIGURE 1: Pearson correlation between small and big acorns per individual.

collection, these seeds would have been included in the same volume group. The scarcity of references about the importance of mother plant in other species [15,22] is peculiar.

In this study, the measurements were performed at the individual tree level because it gives us information on treeto-tree variability within a population. Some trees (8 and 10) would be classified as bigger, because their acorns were placed at the top of the distribution by size shown in Figure 1.

Bigger acorns tended to present higher germination and lower acorn infestation. This fact is very clear at the individual tree level for those trees which presented the same size in different volume classes ( 8 and $10 \mathrm{~S}$ versus $1,2,3,6$, and 16B) (Table 3). If we collected acorns regardless of tree but only the size. All of them would have included in the same class. However, by looking at their behaviour as found, clear differences can be seen in Table 3. This could indicate that each tree, genetic or physiological characteristics, produces a certain size, but also their sizes oriented towards a specific purpose.

4.2. Effect of Size. This study contributes to an understanding of the role of predispersal seed predation by insects and seed size in plant recruitment. Thus, larger seeds also satiated the weevil larvae, and so a larger acorn size increased the likelihood of embryo survival because it has more mass to be consumed [12, 14, 23, 24]. These experiments reinforce the results obtained by others $[12,14,24]$ about the importance of the satiation mechanism by means of larger seeds.

It is well known that predispersive acorn predation by insects is one of the constraints for the sexual regeneration of oak [13], so our results show that the endogenous consumption of seeds gives seed size an important role in the chance of seed's surviving predation.

A negative relationship between seed size and insectinfested acorns ratio was found in our study. The infested percentage was $23.29 \%$ for larger seeds and $65.41 \%$ for small ones, similar to those shown by Espelta et al. [13] for Q. ilex and Q. humilis.

Our study showed a reduction in germination percentage from sound acorns to those damaged by weevils, as observed by other authors [25]. However, infested larger seeds have shown a better germination ratio than infested smaller acorns according to the results found in other experiments $[14,22$, 24]. To understand this result we should be aware of two facts: first, that a larger acorn size means it has larger cotyledons and second that insects oviposit on the basis of acorn, near the cupule [26]. Thus, the larvae began to consume the cotyledons from the base to the embryonic apex. So, the higher size acorn should have greater probability that its embryo will not be damaged, unlike what happens with small seed.

4.3. Ecological Implications. Our results show that cork oak has not only large intraspecific seed-size variability but also per tree. This variability is regarded as an important aspect in the evolution of angiosperms [17]. The seed size of a species represents the amount of maternal investment in the individual offspring [16]. This variability, together with its advantages, could be considered at the species level or at the ecosystem level. At the individual tree level, it presents a strategy to improve the seedling success, because larger seeds have more resources [17]. Thus the seed size variability at 
the individual level tree could be a reproductive strategy. Our study showed how not only important acorn size but also size within the tree ( 8 and 10 S versus $1,2,3,6$, and 16B).

From another point of view, it could be possible that each tree produces different sizes with different roles, for example, small sizes to satisfy its predators; this would agree with those authors who find that birds choose infested acorns [27]. This situation also maintains the genetic variability in the population. On the other hand, larger seed sizes could be more appreciated by rodents as showed by Muñoz and Bonal [28].

In summary, we can conclude that it is important to distinguish acorn size at the individual tree level, not just at the stand level, because they show different behaviours. Furthermore, we postulate that cork oak represents a good reproductive strategy based on two ways that are not contradictory. Each tree could produce two acorn sizes in order to obtain different objectives: smaller ones could be produced for pest satiation and larger ones to produce seedlings. The same strategy may be followed by the whole stand, increasing the genetic variability at stand level.

\section{Acknowledgments}

The authors thank the staff members of the forestry department of the SIDT Junta de Extremadura for assistance with technical work and Mr. Manolo Méndez for permission to work with the cork oak placed in his dehesa. The first author also thanks Dr. J. López, Dr. A. Ortega-Olivencia, and Dr. T. Rodríguez-Riaño from Botany Área of Extremadura University for considerably improving this paper. This study was financed by INIA Projects Ph.D. Thesis "Biología reproductiva de una masa de alcornoque (Quercus suber L.) en el Sur de Badajoz (España)."

\section{References}

[1] R. Corti, "Ricerche sul ciclo riproduttivo di specie del gen. Quercus della flora italiana I. Osservazioni sul ciclo riproduttivo in Quercus coccifera L.," Annali Accademia Italiana di Scienze Forestali, vol. 2, pp. 235-264, 1954.

[2] P. Bianco and B. Schirone, "On Quercus cocciferaL. s.l.: variation in reproductive phenology," Taxon, vol. 34, no. 3, pp. 436-439, 1985.

[3] R. Currás and E. Laguna, "Datos sobre la fenología de algunas especies forestales valencianas," Montes, vol. 10, pp. 50-52, 1986.

[4] R. Corti, "Ricerche sul ciclo riproduttivo di specie del gen. Quercus della flora italiana II. contributo alla biologia ed alla sistematica di Quercus suber L. in particulare delle forme a sivilupo biannale della ghianda," Annali Accademia Italiana di Scienze Forestali, vol. 4, pp. 55-136, 1955.

[5] J. A. Elena-Roselló, J. M. de Rio, J. L. García, and I. G. Santamaría, "Ecological aspects of the floral phenology of the cork-oak (Q. suber L.): why do annual and biennial biotypes appear?" Annals of Forest Science, vol. 50, pp. 114s-121s, 1993.

[6] P. M. Díaz, Variabilidad de la fenología y del ciclo reproductor de Quercus suber L. en la península Ibérica [Ph.D. thesis], 2000, http://oa.upm.es/814/.

[7] J. M. Montoya, "Efectos de la profundidad de siembra y del tamaño de la bellota en el repoblado de Quercus suber L.," Anales INIA: Serie Forestal, vol. 6, pp. 9-16, 1982.
[8] J. L. García Valdecantos, "Influence of seed weight on the early growth of Quercus suber L. seedlings," The International Plant Propagators Society, vol. 35, pp. 432-436, 1985.

[9] M. Pardos, I. Cañellas, and A. Bachiller, "Influencia del tamaño de bellota y del régimen de riego en la calidad de planta de alcornoque cultivada en vivero. II Congreso Forestal Español," Pamplona, vol. 3, pp. 23491-37496, 1997.

[10] C. Bonfil, "The effects of seed size, cotyledon reserves, and herbivory on seedling survival and growth in Quercus rugosa and Q. Laurina (Fagaceae)," American Journal of Botany, vol. 85, no. 1, pp. 79-87, 1998.

[11] G. Ke and M. J. A. Werger, "Different responses to shade of evergreen and deciduous oak seedlings and the effect of acorn size,” Acta Oecologica, vol. 20, no. 6, pp. 579-586, 1999.

[12] R. Bonal, A. Muñoz, and M. Díaz, "Satiation of predispersal seed predators: the importance of considering both plant and seed levels," Evolutionary Ecology, vol. 21, no. 3, pp. 367-380, 2007.

[13] J. M. Espelta, P. Cortés, R. Molowny-Horas, and J. Retana, "Acorn crop size and pre-dispersal predation determine interspecific differences in the recruitment of co-occurring oaks," Oecologia, vol. 161, no. 3, pp. 559-568, 2009.

[14] X. F. Yi and Y. Q. Yang, "Large acorns benefit seedling recruitment by satiating weevil larvae in Quercus aliena," Plant Ecology, vol. 209, no. 2, pp. 291-300, 2010.

[15] J. Tecklin and D. D. McCreary, "Acorn size as a factor in early seedlings growth of blue oaks," in Proc. Symp. Oak Woodlands and Hardwood Rangeland Management, R. B. Standiford, Ed., vol. 126 of USFS Gen. Tech. Rep. PSW, pp. 48-53, 1991.

[16] M. R. Leishman, I. J. Wright, A. T. Moles, and M. Westoby, "The evolutionary ecology of seed size," in Seeds: The Ecology of Regeneration in Plant Communities, M. Fenner, Ed., pp. 31-57, CABI Publishing, Wallingford, UK, 2nd edition, 2000.

[17] S. M. Mandal, D. Chakraborty, and K. Gupta, "Seed size variation: influence on germination and subsequent seedling performance in Hyptis suaveolens, Lamiaceae," Research Journal of Seed Science, vol. 1, pp. 26-33, 2008.

[18] S. Ramos, Biología reproductiva de una masa de alcornoque, Quercus suber L., en el sur de Badajoz [Ph.D. thesis], Universidad de Extremadura, Badajoz, Spain, 2003, http://dialnet.unirioja .es/servlet/tesis? codigo $=525$.

[19] G. Montero and I. Cañellas, Manual de Reforestaciñon y Cultivo de Alcornoque (Quercus suber L.), Instituto Nacional de Investigaciones Agrarias y Alimetnarias, Madrid, Spain, 1999.

[20] R. R. Sokal and F. J. Rohlf, Biometry. The Principles and Practice of Statistics in Biological Research, W. H. Freeman, New York, NY, USA, 3rd edition, 2000.

[21] M. Ferrán, SPSS Para Windows. Análisis Estadístico, McGrawHill, Madrid, Spain, 2001.

[22] M. J. Leiva and R. Fernández-Alés, "Holm-oak (Quercus ilex subsp. Ballota) acorns infestation by insects in Mediterranean dehesas and shrublands: Its effect on acorn germination and seedling emergence," Forest Ecology and Management, vol. 212, no. 1-3, pp. 221-229, 2005.

[23] A. T. Moles and M. Westoby, "Seedling survival and seed size: a synthesis of the literature," Journal of Ecology, vol. 92, no. 3, pp. 372-383, 2004.

[24] Z. Xiao, M. K. Harris, and Z. Zhang, "Acorn defenses to herbivory from insects: implications for the joint evolution of resistance, tolerance and escape," Forest Ecology and Management, vol. 238, no. 1-3, pp. 302-308, 2007. 
[25] J. A. Lombardo and B. C. McCarthy, "Seed germination and seedling vigor of weevildamaged acorns of red oak," Canadian Journal of Forest Research, vol. 39, no. 8, pp. 1600-1605, 2009.

[26] F. J. Soria and M. E. Ocete, "Principales Tortrícidos perforadores del fruto del alcornoque en la Sierra Norte de Sevilla," Boletín de Sanidad Vegetal Plagas, vol. 22, no. 1, pp. 63-69, 1996.

[27] W. C. Johnson, L. Thomas, and C. S. Adkisson, "Dietary circumvention of acorn tannins by blue jays-implications for oak demography," Oecologia, vol. 94, no. 2, pp. 159-164, 1993.

[28] A. Muñoz and R. Bonal, "Are you strong enough to carry that seed? Seed size/body size ratios influence seed choices by rodents," Animal Behaviour, vol. 76, no. 3, pp. 709-715, 2008. 

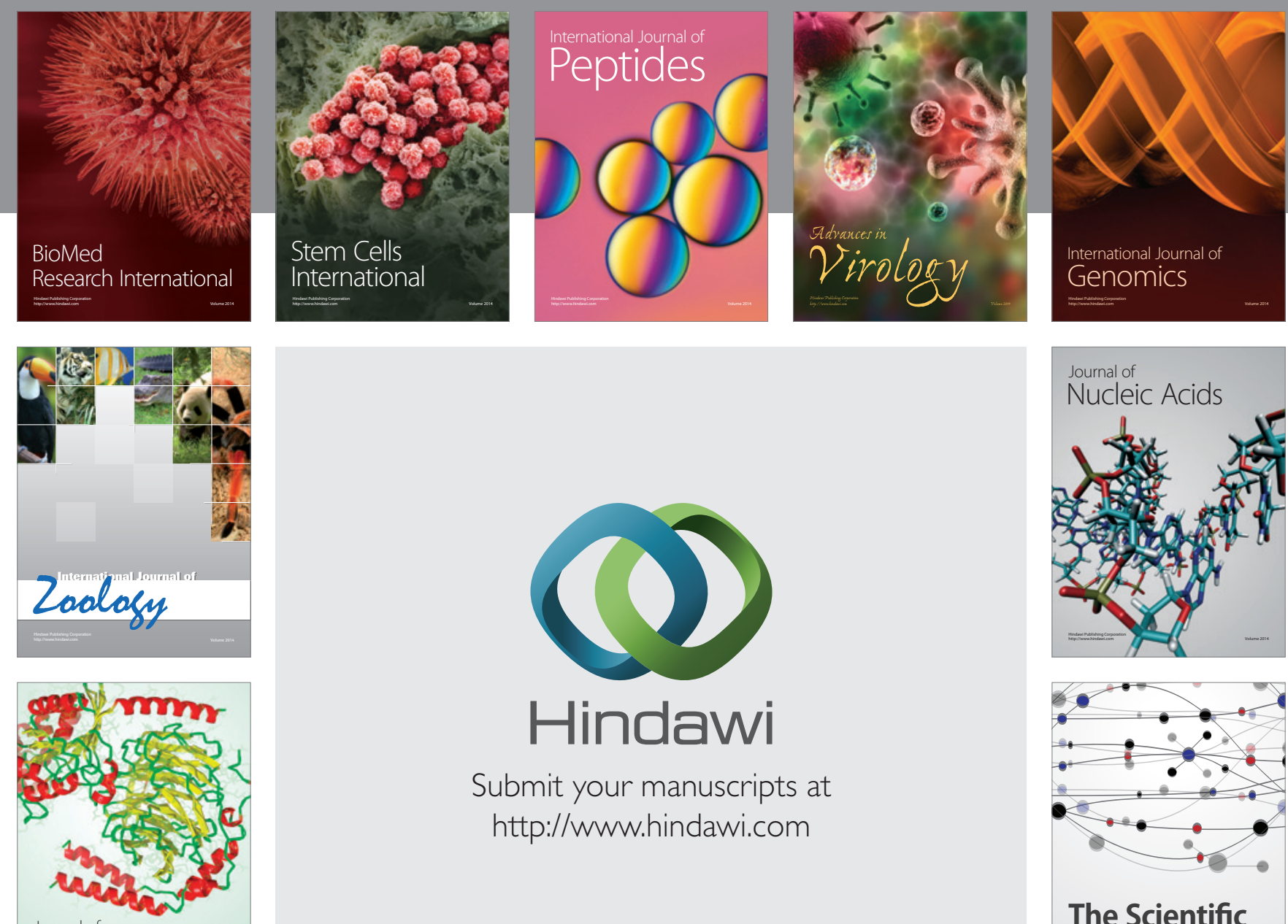

Submit your manuscripts at

http://www.hindawi.com

Journal of
Signal Transduction
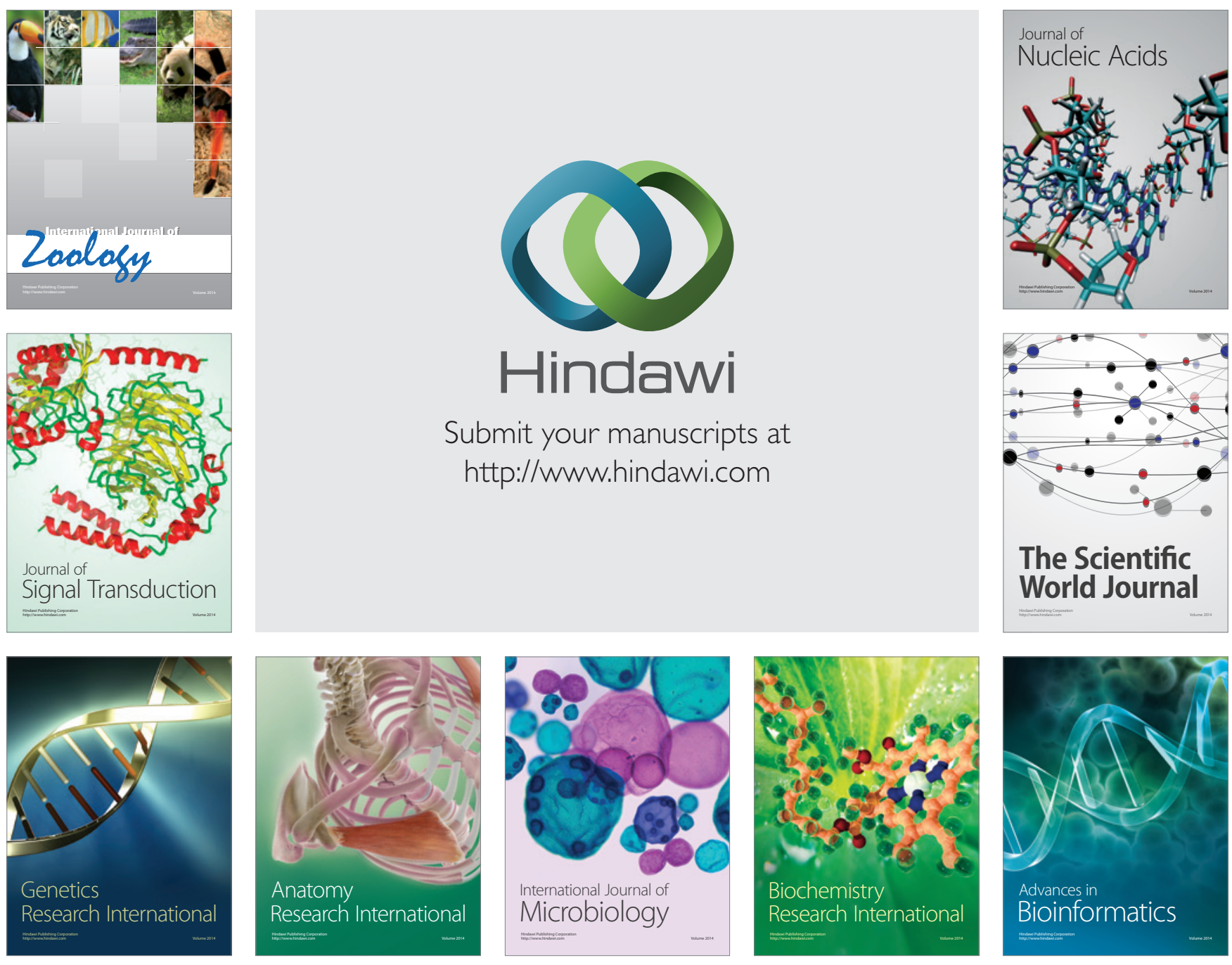

The Scientific World Journal
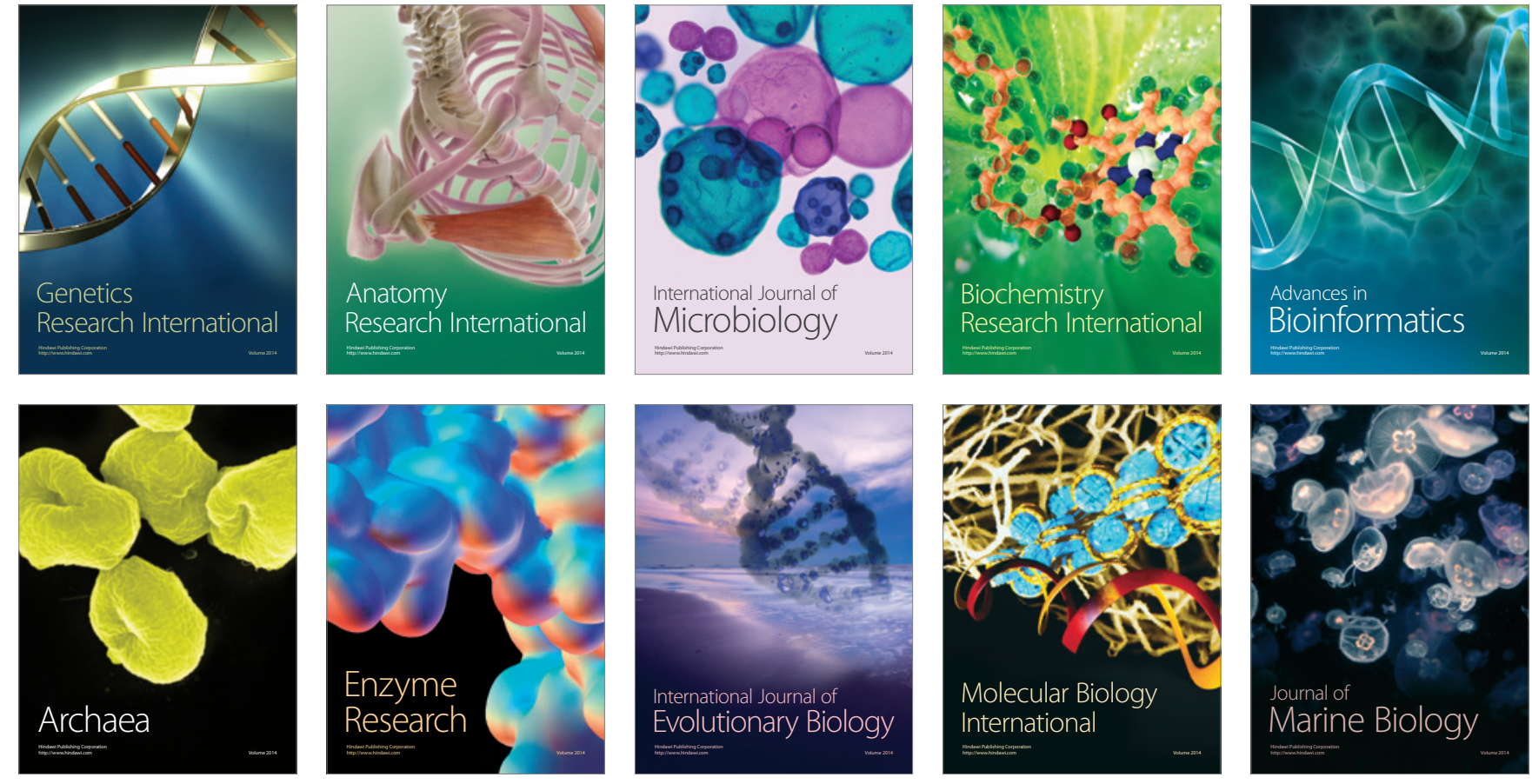